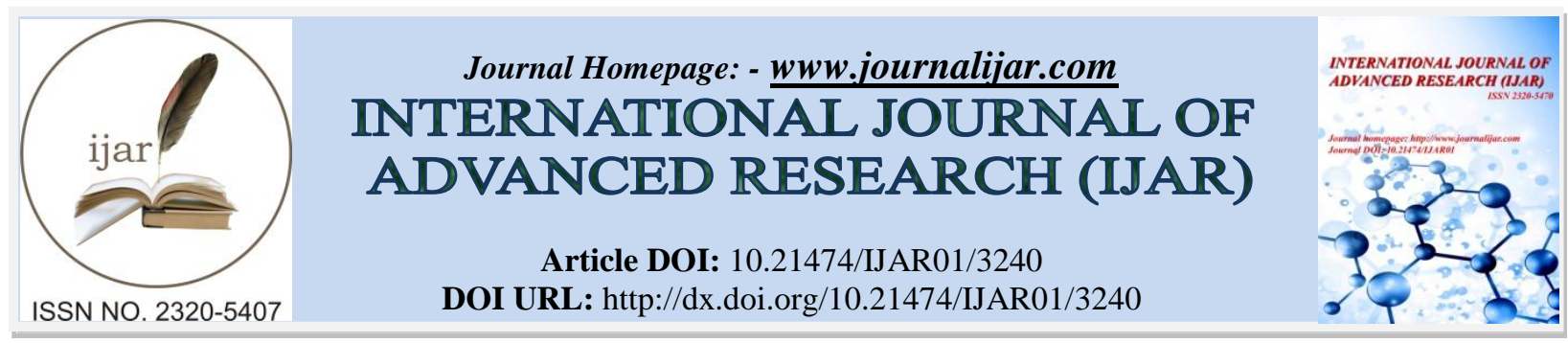

RESEARCH ARTICLE

\title{
INVESTIGATION OF USAGE OF PHOTOVOLTAIC SOLAR CELL FOR POWER GENERATION WITH ENVIRONMENTAL IMPACTS.
}

\author{
Dr. E. N. Ganesh.
}

\section{Manuscript Info}

Manuscript History

Received: 20 December 2016

Final Accepted: 20 January 2017

Published: February 2017

\section{Key words:-}

Life Cycle Assessment, Multicrystalline silicon modules, CdTe technology, Energy analysis, Resource depletion, Module decommissioning, Emissions to the environment, Health and safety risks.

\begin{abstract}
In this paper the authors have shown the other aspect of photo voltaic cells. A burning issue in the energy sector is to find out the appropriate alternative resource of power generation, due to the rising rate of consumption and price of fossil fuels and the environmental problems caused by the conventional power generation methods, among all the available alternatives non-conventional resources, photovoltaic cell can be considered the most essential and sustainable source for power generation. But this paper discuss about the combative picture between the utilization of photovoltaic cells and the production of photovoltaic cells related with the environmental aspects
\end{abstract}

Copy Right, IJAR, 2017,. All rights reserved.

\section{Introduction:-}

It is widely recognized that photovoltaic solar energy conversion has the potential to become a major energy source in the next century. Although photovoltaic solar energy (PV) is clearly a renewable energy source, the question whether it is also a "sustainable technology" needs more careful consideration. The potential environmental risks and the energy requirements of (the components of) a PV system should be investigated over its entire life-cycle in order to answer this question. If such analyses are made before large-scale implementation of the technology has started, potential bottlenecks can be identified so that R\&D priorities can be set accordingly to reduce or eliminate the bottlenecks beforehand. As a result of such an environmental assessment it might be decided for instance to start investigations on alternatives with regard to cell materials, production technologies or module encapsulation techniques. To conduct a series of studies on potential environmental and safety risks for a number of solar cell technologies. The objective of the studies is to identify potential bottlenecks for each technology and to formulate ensuing recommendations with regard to the photovoltaic policy. In the study the potential environmental effects of PV modules are investigated for their entire life-cycle that is from raw material mining through module production and utilization to module decommissioning and, possibly, recycling. It was agreed that four different types of solar cells would be investigated in these studies, namely:

1) Multicrystalline silicon cells ( $\mathrm{mc}-\mathrm{Si}$; also called semi-or polycrystalline silicon);

2) Amorphous silicon cells (a-Si);

3) Cadmium telluride cells (CdTe);

4) Copper indium selenide cells ( $\mathrm{CuInSe}_{2}$; also shortened to CIS);

The studies concerning the above-mentioned cell technologies are discussed in three separate headings. In this report We will present a summary of the method of approach and the obtained results for all four cell types. It should be noted, however, that the methodology and the scope of the analyses has developed in the course of the discussion.. 
In our own studies which form the basis for this summary report we have tried to integrate results in the framework of the Life Cycle Assessment (LCA) methodology and to extend the scope towards future technologies which seem probable for large-scale module production. In order to understand the sensitivity of the results with respect to possible future developments, we will draw up three different sets of assumptions concerning the future status of the technology for each cell type. These sets of assumptions will be called A,B and C case technology. In this paper the $\mathrm{B}$ case represents the most probable technological status at the time of large-scale deployment. The A case reflects the status of present-day commercial production technology. Finally, the $\mathrm{C}$ case represents an more optimistic view on future technology. As already indicated, this discussion will be limited to a life-cycle assessment of solar cell modules. In this paper we will first introduce briefly the method of environmental Life Cycle Assessment and further define the goal and scope of our assessment study. Subsequently, we will discuss the most important assumptions concerning module and cell characteristics, production methods, etc. Next, some results are presented, among which the expected emissions to the environment and the energy requirements. Finally we will draw some conclusions concerning potential environmental bottlenecks of PV modules.

\section{Life Cycle Assessment:- LCA goal:}

In this study we want to investigate the environmental bottle-necks which might arise when PV modules are deployed on a large scale for energy supply. A consequence of this objective is that production levels of the order of GWp's per year should be considered rather the current MWp production level. As a reference one can keep in mind that a yearly solar cell production of more than $10 \mathrm{GWp} / \mathrm{yr}$ will be required to sustain a PV capacity that can contribute $5 \%$ to current electricity supply.

\section{LCA Method:-}

In the Analysis we made use of the method of environmental Life Cycle Assessment (LCA), a methodological framework for the analysis of environmental aspects of product life-cycles, which has evolved over the past few years. In such a LCA the material and energy flows for the entire life cycle of a certain product are surveyed and analyzed with special attention to possible environmental hazards. For this purpose the product life cycle is divided into a number of processes, each of which is described by the typical product input and output flow, secondary material inputs, energy input, process yield, water and air emissions, solid waste production and the output of reusable (secondary) materials. By chaining a number of relevant processes into a product life cycle and accounting all material flows through these processes it becomes possible to assess the total impact on the environment and on energy and raw material resources for the entire product life cycle. One consequence of our study objective is that we will have to make projections about the technological status of future production processes. Because this necessarily involves major uncertainties we will distinguish three cases: the A case reflecting the status of presentday commercial production technology, the B case representing the most probable technological status at the time of large-scale deployment, and finally the $\mathrm{C}$ case representing an optimistic view on technology development. For the B case technology we assume implementation within the next 10 years, while the time frame for the (possible) realization of $\mathrm{C}$ case technology is 15 years. Regarding our assessment method it should further be noted that in a full Life Cycle Assessment a certain procedure is followed involving a number of steps, such as: definition of LCA goal and scope, drawing up of the inventory table of environmental interventions and classification and evaluation of these interventions. For the purpose of this study where we consider future production technologies not all of the prescribed LCA steps are relevant or practicable, because of lack of data etc. For these reasons our studies cannot claim to be "full" LCA studies, in which the majority of the material flows is inventoried and the environmental impacts are evaluated. For example in our first study on CdTe and CIS modules, we restricted the material flow analysis to the elements $\mathrm{Cd}$, Te, Se, and In and did not consider any auxiliary material usage. The main reason for this was the lack of detailed information on (future) production processes for these module types. Also at that time the methodological framework for Life Cycle Assessments had not yet been fully developed so that the terminology and reporting format in our study deviates from the standards which later evolved for LCA studies. In the amorphous silicon study and the mulitcrystalline silicon study we had access to more detailed data on production technology which allowed us to the take into account most material flows. Also we adhered more closely to the "standards" regarding LCA terminology and study set-up. Still, we decided not to perform an analysis of environmental impacts after our investigation of material flows, because: 1) there are insufficient data to allow an reliable impact evaluation for all emitted substances and 2) emission estimates for the future technology cases (B and $\mathrm{C}$ case) are often to uncertain to make reliable impact evaluations for these cases. 


\section{LCA scope and the functional unit:-}

The scope of our material flow analysis is restricted to direct material inputs only, which means that the production of for example glass or aluminium is outside our system boundary and is not considered in our analysis .The scope for the analysis of energy requirements, however, is broader and includes also the energy use for the production of glass and aluminium and for the production of capital equipment. In the energy analysis auxiliary materials which are used in relatively small quantities (e.g. solvents, etchants, hydrogen, argon) were not taken into account, mainly because energy data are unavailable for most of these products. Figures 2.1 and 2.2 illustrate the definition of the system boundaries for the materials and energy analyses for the example of mc-Si technology. The scope definition given above implies that the non-energy related emissions from the production of aluminium and glass are not accounted for in this study. Such aspects, however, should be investigated in relation to module mounting technology.The functional unit for our Life-Cycle Assessment, that is the unit of end-product to be considered, we have defined as 1 square meter of cell area, manufactured in a commercial scale production process. If needed, corresponding values per m module area can be derived by applying the cell/module area ratio. The photovoltaic efficiency will refer to the total area stabilized energy conversion efficiency of the cell as it is encapsulated in the module (encapsulated cell efficiency).
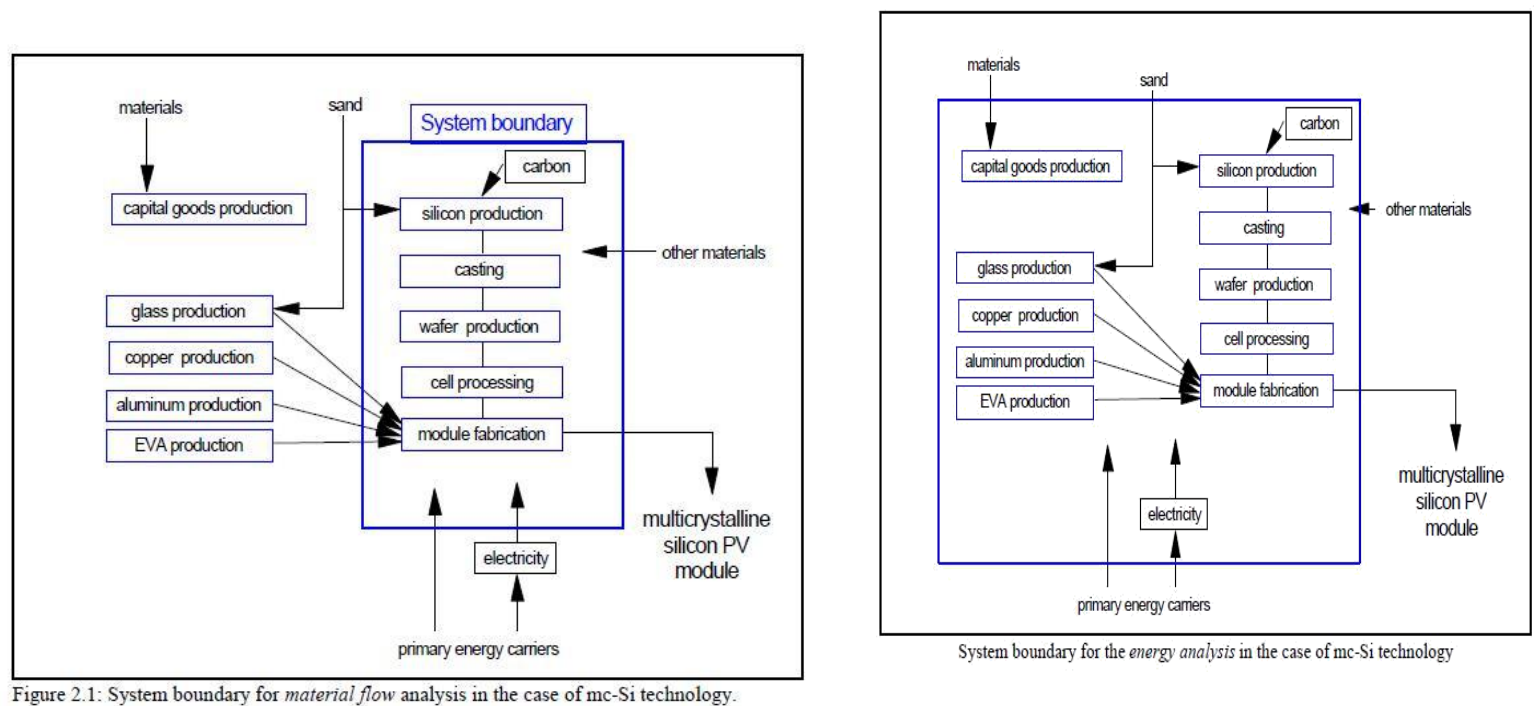

Figure 2 System Boundary Flow for Energy Analysis 3 Major assumptions

\section{Multi-crystalline silicon modules:-}

Cell, module and process characteristics:-

Multicrystalline silicon (mc-Si) technology is one of the major technologies for production of solar cell modules and this type of modules presently has a share of some $25 \%$ of the PV module market. Present-day mc-Si modules are generally composed of 36-40 interconnected solar cells, where each solar cell consists of a silicon wafer with a surface area of about $10 \times 10 \mathrm{~cm}$ and a thickness of 0,2-0,3 mm. Multicrystalline silicon solar cell technology is closely connected to the older mono crystalline solar cell technology (which is still the most important technology with a $60 \%$ market share). The main difference between multi-and monocrystalline silicon solar cell manufacturing is found in the crystallization process, while less important differences may be encountered in the solar cell processing itself (e.g. passivation). To a large extent, however, the material flows and emissions found in multicrystalline silicon technology will also be found in mono crystalline silicon technology. Therefore the results of our study on multicrystalline silicon will probably also give an fair indication of the environmental aspects of monocrystalline silicon technology In our study we assume the encapsulated cell efficiency for mc-Si to improve from $\mathrm{A}$ to $\mathrm{B}$ and $\mathrm{C}$ case from $13 \%$ to $16 \%$ and $18 \%$ respectively, a development which is to be achieved by introducing new technologies and solar cell features. In tables 3.1 and 3.2 an over view is given of the most important differences between the cases. The life cycle of a multicrystalline silicon PV module starts with the mining and refining of silica (quartz). Silica is reduced with carbon and the reduction step is either followed or preceded by a purification step. For the A and B case we depart from the process developed by Union Carbide Corp. 
in which $\mathrm{SiCl} 4$ is hydrogenated and subsequently distilled to semiconductor grade (sg) silane. This silane can then be converted to solid polycrystalline silicon, or it can be used as source gas for amorphous silicon solar cell production. Subsequently the high purity polycrystalline silicon is melted and cast into large blocks of multi-(or semi-)crystalline silicon. The blocks are portioned into ingots, which are subsequently sliced into wafers. The wafers are processed into solar cells by etching, texturing, formation of the emitter layer, application of back surface layer and contacts, passivation and deposition of the antireflective coating. Finally the solar cells are tested, interconnected and subsequently encapsulated and framed into modules. The application of a back surface layer and the passivation step are omitted in the $\mathrm{C}$ case. The general trend in the expected future developments is towards improved energy and material efficiency. This can be seen in higher process yields for high purity silicon production, casting, portioning and material production, in the usage of thinner wafers, in lowering of the metal coverage factor in contact formation, in the reduction of contouring and wafering losses and in the reduction of process energy requirements. The most influential differences regarding energy and material requirements are the usage of thinner and larger wafers and reducing portioning and wafering losses in $\mathrm{B}$ and $\mathrm{C}$ case, and the development of a production process for solar grade silicon in the $\mathrm{C}$ case.

Table 3.1:- Cell and module characteristics for multicrystalline silicon technology

\begin{tabular}{|c|c|c|c|}
\hline & A case & B case & C case \\
\hline Cell efficiency $^{1}(\%)$ & 13 & 16 & 18 \\
\hline Wafer size $\left(\mathrm{cm}^{2}\right)$ & $10 \times 10$ & $12.5 \times 12.5$ & $15 \times 15$ \\
\hline Wafer thickness $(\mu \mathrm{m})$ & 300 & 200 & 150 \\
\hline Cells/module & 36 & 36 & 40 \\
\hline Module size $\left(\mathrm{m}^{2}\right)$ & 0.44 & 0.65 & 1.00 \\
\hline Cell/module area ratio & 0.82 & 0.87 & 0.90 \\
\hline Moduleefficiency $^{2}(\%)$ & 10.6 & 13.8 & 16.2 \\
\hline \multicolumn{4}{|l|}{ Module structure: } \\
\hline -glass (mm) & 3 & 3 & 3 \\
\hline$-\mathrm{EVA}^{3}(\mathrm{~mm})$ & $2 \times 0.5$ & $2 \times 0.5$ & $2 \times 0.25$ \\
\hline -Tedlar/Al/Tedlar $(\mu \mathrm{m})$ & 125 & 125 & 125 \\
\hline Module life time (yr) & 15 & 25 & 30 \\
\hline
\end{tabular}

1) Efficiency is for the cell as en-capsulated and interconnected in the module.

2) derived values;

3) EVA = Ethyl Vinyl Acetate;

Table 3.2:- Major process characteristics for mc-Si module production.

\begin{tabular}{|l|l|l|l|}
\hline & A case & B case & C case \\
\hline sg-Si & $\mathrm{UCC}^{1}-$ & $\mathrm{UCC}^{1}-$ & reduction \\
\hline production & process & process & of hp- $^{-}$ \\
\hline & & & $\mathrm{SiO}_{2}$ \\
\hline casting & conventional & advanced & electro- \\
\hline & & conventional & 150 \\
\hline Wafering loss & 300 & 200 & \\
\hline$(\mu \mathrm{m})$ & & & 10 \\
\hline Back metal & 100 & 100 & \\
\hline coverage $(\%)$ & & & 6 \\
\hline Front metal & 10 & 7 & \\
\hline coverage $(\%)$ & & & \\
\hline Solar cell & $95 \%$ & $95 \%$ & \\
\hline process yield & & & \\
\hline
\end{tabular}

1) process developed by Union Carbide Corporation to produce solar gradesilane/silicon for cell processing only, not for Si production and wafering.

\section{Module Use:-}

Negligible material inputs and/or emissions are expected during the utilization phase of the module (only from occasional washing). Significant emissions due to fires are not expected from mc-Si modules. In this phase the 
module will produce electrical energy, the amount of which depends on module efficiency and location. Module lifetimes of resp. 15, 25 and 30 years Ire assumed for the three cases.

\section{Module decommissioning:-}

At the end of the module lifetime the PV system will be decommissioned and the resulting waste will have to be disposed in a responsible way. Options for recycling of the silicon wafer have been investigated but are at this moment not commercially available. Because there is hardly any data available on the technology of mc-Si module recycling I did not consider this in our study.

\section{Amorphous silicon modules:-}

\section{Cell, module and process characteristics:-}

Amorphous silicon (a-Si) solar cell technology is very different from crystalline silicon cell technology, in that the amorphous silicon cell consist of a very thin layer of amorphous (i.e. non-crystalline) material. The low requirement of cell material and the possibility of large-area cell manufacturing processes, makes a-Si technology a potential candidate for production of low-cost modules. Furthermore with a-Si there is the possibility of cell stacking, an approach in which two or three different a-Si solar cells are stacked into a tandem or triple structure. And which may ultimately lead to a higher conversion efficiency. Mainly because of their relatively low efficiency a-Si modules have only a modest market share of about $14 \%$ at present. Our A case and B case definitions for the amorphous silicon technology are both Based on a tandem cell structure, be it with differing i-layer thicknesses (see table 3.3). For the $\mathrm{C}$ case I assume a triple-junction structure Based on a-SiC/ a-Si/ a-SiGe. The a-Si layers are deposited on a glass substrate by way of the Plasma Enhanced Chemical Vapour Deposition with a material utilization rate which increases from 15 to $70 \%$ (table 3.4). In all three cases the front-side contact layer consists of tin oxyde doped with fluorine and deposited by CVD, while the back-contact consists of a sputtered or evaporated aliminium layer. The silane source gas for a-Si deposition is produced by the same process from Union Carbide Corp. which was assumed for the mc-Si technology. .Module encapsulation is changed from two glass sheets for the A and B case $(2 \times 3 \mathrm{~mm}$ resp. $2 \times 2 \mathrm{~mm})$, to one $2 \mathrm{~mm}$ glass sheet with a sprayed-on back-side foil in the C case. Module use Considerations for the module utilization phase are similar as for mc-Si.

\section{Module decommissioning}

After decommissioning the a-Si module can be disposed as solid waste without problems as all module components (including metals) are inert or relatively harmless. Recycling of the glass or reuse of the glass sheet plus $\mathrm{SnO}_{2}$-layer is possible in principle. However, to maintain comparability with other considered module types I have not considered the effects of these recycling options.

Major process characteristics for a-Si module Table 3.3

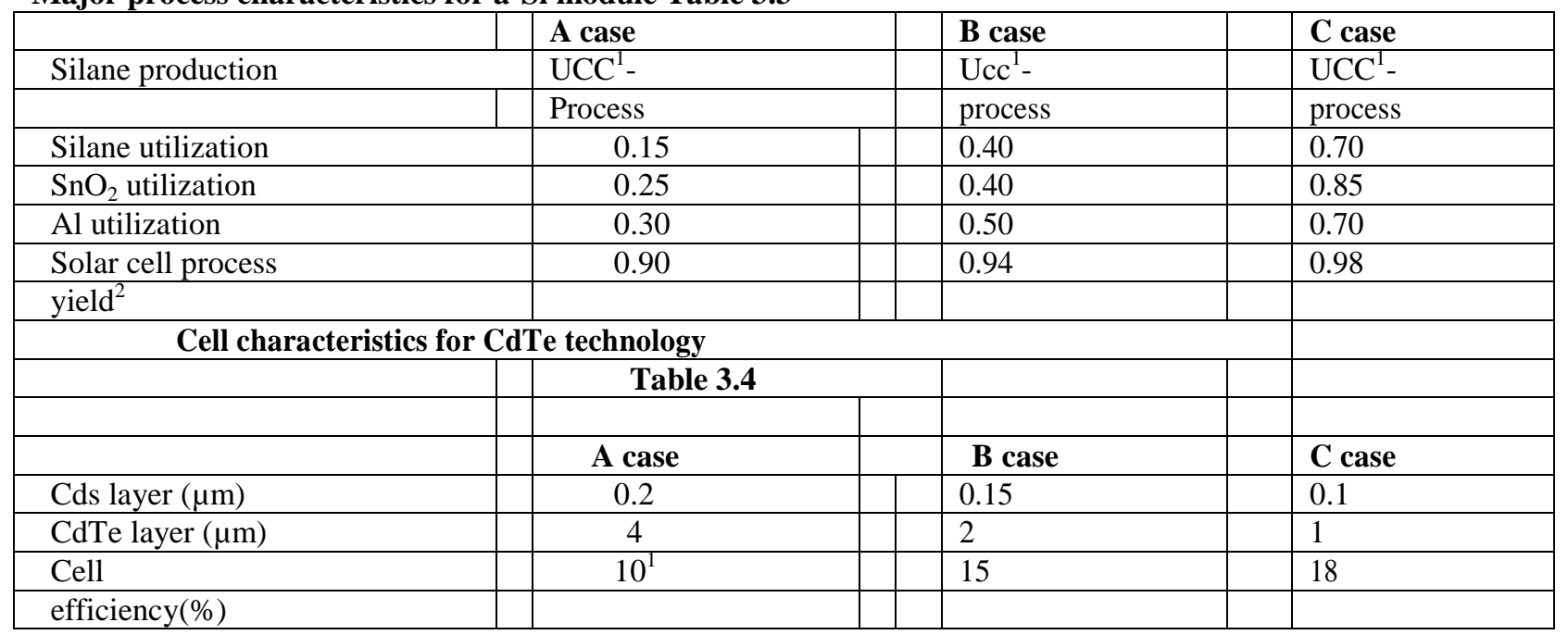


Table 3.5:- Cell characteristics for CIS technology

\begin{tabular}{|l|l|l|l|}
\hline & A case & \multicolumn{1}{|c|}{ B case } & C case \\
\hline Cds layer $(\mu \mathrm{m})$ & 0.1 & 0.05 & 0.02 \\
\hline CdTe layer $(\mu \mathrm{m})$ & 4 & 2 & 1 \\
\hline $\begin{array}{l}\text { Cell } \\
\text { efficiency }(\%)\end{array}$ & $10^{1}$ & 15 & 18 \\
\hline
\end{tabular}

\section{CdTe and CIS modules:-}

\section{Cell, module and process characteristics}

Cadmium telluride (CdTe) and copper indium selenide (CuInSe $e_{2}$; also: CIS) solar cells are two other representatives of thin-film solar cell technology, which is characterized by the use very thin layers of cell material $(<50 \mu \mathrm{m})$. For CdTe and CIS modules also good prospects exist for low-cost production processes and for efficiency enhancement by way of cell stacking. Production technology for CdTe and CIS solar cells is much less established than for mc-Si and a-Si. CdTe modules are produced only on a small scale while CIS cells have up to now not been produced on commercial basis. Specific data about production technology are therefore scarce. For this reason I have limited our investigation of CdTe and CIS technology to assessment of the material flows for $\mathrm{Cd}$, Te, In, and Se and to an analysis of the energy requirements. Table 3.4, 3.5 and 3.7 summarize the main cell and module characteristics that we have assumed for CdTe respectively CIS modules. Note that, in deviation of the assumption for a-Si modules, and in deviation of our original study, I have maintained the back glass cover for the $\mathrm{C}$ case CdTe/CIS module. Reason for this is that lower emissions of heavy metals, especially in fires and in waste dump sites are expected from modules with a back glass cover.

Table 3.7:- Module characteristics for CdTe and CIS technology.

\begin{tabular}{|l|l|l|l|l|}
\hline & & \multicolumn{1}{|c|}{ A case } & \multicolumn{1}{|c|}{ B case } & \multicolumn{1}{c|}{ C case } \\
\hline Module structure: & & & & \\
\hline -front glass (mm) & & 3 & 2 & 2 \\
\hline -EVA (mm) & & 0.5 & 0.5 & 0.5 \\
\hline -back glass (mm) & & 3 & 2 & $2^{1}$ \\
\hline & & & & \\
\hline Module size $\left(\mathrm{m}^{2}\right)$ & & 1 & 1 & 1 \\
\hline Cell/module & area & 0.94 & 0.94 & 0.94 \\
\hline ratio & & & & \\
\hline Module & & 9.4 & 14.1 & 16.9 \\
\hline efficiency $(\%)$ & & & & \\
\hline Module life time $(\mathrm{yr})$ & & $15^{3}$ & $25^{3}$ & 30 \\
\hline
\end{tabular}

Regarding the production technology I assume for deposition of the CdS and CdTe layers in the CdTe cell that the electrode position process will be employed, with material utilization factors of 90 to $99 \%$ (table 3.8). For the CIS cell first the CdS layer is sputtered, while the CIS layer is prepared by physical vapor deposition of copper and indium followed by selenization (reaction with $\mathrm{H}_{2} \mathrm{Se}$ gas).

Table 3.8:- Major production process characteristics for CdTe and CIS technology.

\begin{tabular}{|l|l|l|l|l|}
\hline & & A case & B case & C case \\
\hline CdTe cell & material & 0.90 & 0.95 & 0.99 \\
\hline & utilization & & & \\
\hline CIS cell & $(\mathrm{Cd}, \mathrm{Te})$ & & & \\
\hline & material & 0.60 & 0.70 & 0.80 \\
\hline & utilization & & & \\
\hline Process yield & $(\mathrm{Cd}, \mathrm{In}, \mathrm{Se})$ & & & \\
\hline Cd emission to air (mg/kg) & 1 & 0.60 & 0.70 & 0.80 \\
\hline Se,Te. In emission to air & 500 & 100 & 50 \\
\hline$(\mathrm{mg} / \mathrm{kg})^{2}$ & 5000 & 1000 & 500 \\
\hline
\end{tabular}




\section{Note: 1) cell/module production only 2) emission in mg per kg:-}

The environmental impacts from the mining of $\mathrm{Cd}$, In, Se and Te, materials which are all produced as a byproduct of zinc or copper mining, have been calculated as a fraction the total impact of the mining process. Based on the economic value of by-product and main product these fractions were set at respectively $2.5 \%, 0.2 \%, 0.2 \%$ and $0.36 \%$.The $\mathrm{B}$ case emission rates for $\mathrm{Cd}$ were based on emission data of a cadmium production facility in The India. Because emission control for Se, Te and In will probably be less strict I have assumed emission rates for these substances to be a factor 10 higher.

\section{Module use}

During use of the modules there is a risk that they will be involved in a fire. This is especially the case for modules installed on the roof of a building. Emission of a certain fraction of cell material in CdTe and CIS cells may then occur. Although acute health risks from these emissions are improbable, the overall environmental impacts still need consideration. Therefore an estimate of the fire risks and A to $\mathrm{C}$ case assumptions for the emitted fraction have been made (table 3.9). Different other routes for human exposure to $\mathrm{Cd}$, Te or Se during the use of CdTe and CIS modules have also been investigated. but in all cases the risks Ire found to be small.

Table 3.9: Assumptions on emissions from module use and decommissioning for CdTe and CIS technology.

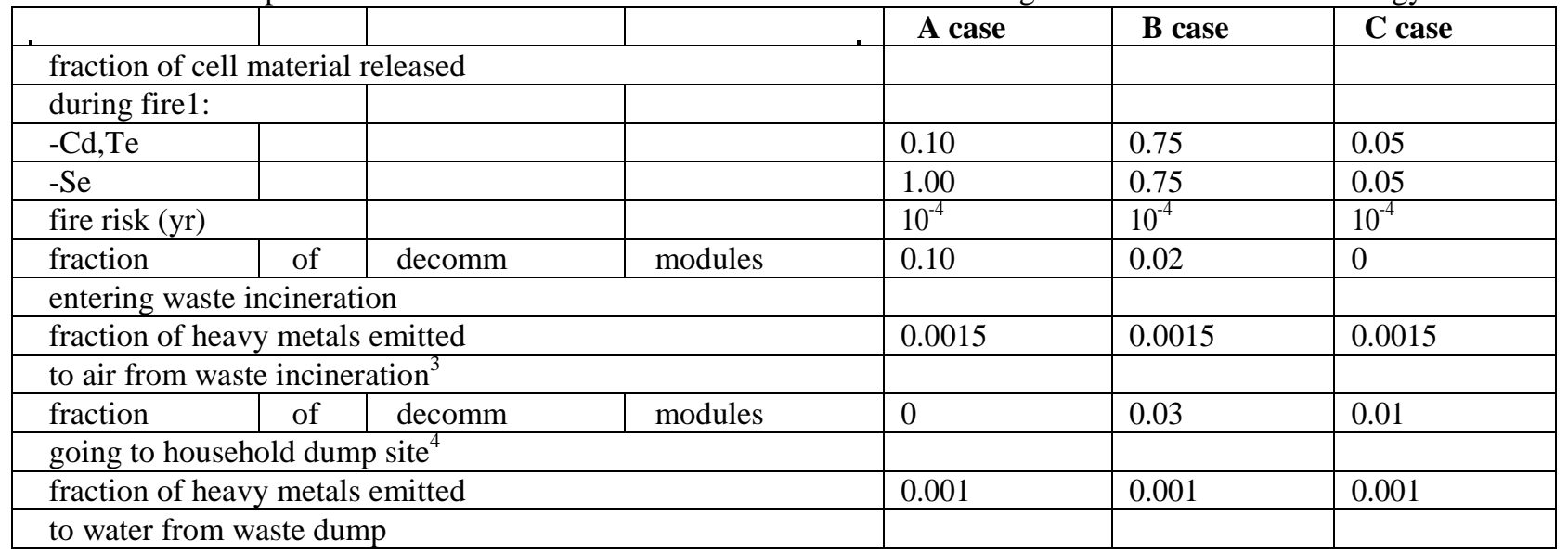

\section{Module decommissioning}

In view of the heavy metal content of CdTe and CIS modules separate collection of decommissioned modules seems advisable. However, it is probable that a small fraction of the modules will still end up in household waste which may either be incinerated or disposed of at a landfill site. In each case a certain emission of the heavy metals to the environment will result. Relevant assumptions to estimate these emissions are given in table 3.7.Although recycling of CdTe and CIS modules is subject of investigations, there is not sufficient data to consider the effects of a possible recycling process at this time.

\section{Energy analysis:- \\ Introduction:-}

In this chapter, we will analyze the Gross Energy Requirement (GER) of the considered solar cell modules. A GER value gives the total amount of primary energy incorporated in a product, as a result of all the production processes necessary to manufacture it, including the heating value of the product (if relevant). The energy required in a specific process step is called the Process Energy Requirement (PER). This PER can be separated into a direct and an indirect part where the first value gives the electrical and fuel energy which is consumed in the production process itself, while the indirect PER represents the "overhead" amount of energy consumption due to for example lighting, heating and ventilation. So cumulation of all PER values for the subsequent steps in a production process and summation with the product' s heating value results in the GER value of the product. and our analysis of module GER values I will distinguish the following contributions: the Gross Energy Requirement of the input materials (GER input), the Process Energy Requirements (PER) and the Gross Energy Requirement of the capital goods (GER capital).Energy required for the production of the input materials like glass or EVA is also taken into account. In the B and C cases a 10\% resp 20\% autonomous reduction on the Process Energy Requirements is assumed for commodities like glass, EVA and aluminium. Although energy requirements will generally be a mix of thermal (fuel) and an electrical energy all results will be presented here in thermal energy units. For the conversion of 
thermal energy units $\left(\mathrm{kWh}_{\mathrm{th}}\right)$ to electrical energy units $\left(\mathrm{kWh}_{\mathrm{e}}\right)$ a factor of resp. $0.39,0.42$ and 0.45 was used, reflecting the expected improvements in average conversion efficiency of the electricity supply. The Energy PayBack Time (EPBT) for the different cases will also be presented. This EPBT will be calculated for a PVsystem under indian irradiation conditions $(1000 \mathrm{kWh} / \mathrm{m} / \mathrm{yr})$ and" global average" irradiation $(1700 \mathrm{kWh} / \mathrm{m} / \mathrm{yr})$. Furthermore I assumed a yearly Performance Ratio (a measure of system performance) of respectively 0.75 , 0.80 and 0.85 for the A,B and C case. Appendix A gives an overview of energy production data per m module area in the different cases. Note that energy pay-back times are given for frameless modules only because Balance-of-system components like support structures etc. Ire not evaluated in our studies and because framing requirements are dependent on the method of installation of the modules.

\section{Material flow analysis:- \\ Introduction:-}

For all four cell types I have analyzed material flows and estimated emissions due to module production. In these analysis I have considered only direct material inputs, so the production of commodities, like aluminum and glass, and capital goods was not taken into account. A comprehensive overview of all material requirements and emissions is impossible in the context of this summary report, therefore I will highlight a few notable aspects per cell type, beginning with the issue of resource depletion.5.2 Resource depletionIn order to evaluate resource depletion impacts I will estimate the material requirements if $5 \%$ of the current world electricity production is supplied by means of one specific type of solar cell modules (B case variant). This would mean that can $13 \mathrm{GWp}$ of solar cell modules have to be produced annually. The corresponding material requirements will be compared with current production levels and estimated reserves. As no recycling technologies are currently available for solar cell modules, the effect of recycling of resource materials will not be considered here.

\section{mc-Si modules:-}

Quartz sand, the primary feedstock material for production mc-Si cells, is very abundant so on this point resource availability will probably never be an issue. One point of concern, however ,is the consumption of silver for the contacts. It was estimated that about $50 \mathrm{~g}$ of silver is required per m cell area, so that supply of $5 \%$ of electricity consumption would require 4 kton of silver per year or $30 \%$ of the current silver production (table 5.1). So reduction of silver use in the contacts is of importance. Probably a reduction of silver use will also be pursued for reasons of cost reduction. In fact, the silver requirement in our $\mathrm{C}$ case mc-Si modules is only $7 \%$ of the $\mathrm{B}$ case requirement.

\section{CdTe and CIS modules:-}

For production of B case CdTe modules about 60 ton/ GWp of both $\mathrm{Cd}$ and Te is required. In view of current production levels and estimated reserves (table 5.2) the supply of cadmium will not be a bottleneck. The supply of tellurium, hoIver, may become a problem if CdTe modules are to contribute significantly to the world electricity supply. Te is mainly produced as byproduct of copper, and as such the production capacity may be limited to 400 ton maximum. For B case CIS module production about 70 ton of indium and 125 ton of selenium is needed. Current indium production is very small (140 ton/y) and the maximum production capacity as a by-product of zinc winning may be limited to 1000 tons. Also the reserves may be depleted within a few years if CIS modules are to supply $5 \%$ of the world electricity production. Selenium supply, on the other hand, will be much less problematic. The resource requirements for the $\mathrm{A}$ and $\mathrm{C}$ case $\mathrm{CdTe}$ and $\mathrm{CIS}$ modules can be found by multiplication with a factor 5 resp. 0.35. In view of these resource considerations recycling of the metals in CdTe and CIS modules will become a point of major importance if these module types are to be implemented on a large scale.

Table 5 :- Resource material requirements for PV module roduction winning.

\begin{tabular}{|l|l|l|}
\hline Cell & resource & Requirement for 5\% electr. Prod. \\
\hline type & material & by PV (kton/y) \\
\hline $\mathrm{mc}-\mathrm{Si}$ & $\mathrm{Si}$ & 120 \\
\hline $\mathrm{mc}-\mathrm{Si}$ & $\mathrm{Ag}$ & 4 \\
\hline $\mathrm{a}-\mathrm{Si}$ & $\mathrm{Si}$ & 0.3 \\
\hline $\mathrm{CdTe}$ & $\mathrm{Cd}$ & 0.8 \\
\hline $\mathrm{CdTe}$ & $\mathrm{Te}$ & 0.8 \\
\hline $\mathrm{CIS}$ & $\mathrm{In}$ & 0.9 \\
\hline
\end{tabular}




\section{Emissions to the environment:- \\ General remarks:-}

For all module types the material balance is dominated by the bulk type materials used for module encapsulation (glass, EVA). Also waste emissions consisting of rejected order commissioned modules form an important contribution (in mass terms). For the thin film type of modules (a-Si, CdTe, CIS) the emission of tin to the water resulting from the TCO deposition process, is a point of attention. With respect to different cases one may remark that, going from A to $\mathrm{C}$ case, the general trend for increased material efficiency will mostly lead to decreasing emissions per unit cell area. Furthermore emissions on energy-basis, which are more relevant in comparisons with other energy technologies, will of course benefit from the increasing cell performance.

\section{mc-Si modules:-}

Environmentally relevant substances which may be released in multicrystalline silicon PV module production are fluorine, chlorine, nitrate, isopropanol, $\mathrm{SO}_{2}, \mathrm{CO}_{2}$, respirable silica particles and solvents. Emissions of (non-energyrelated) $\mathrm{CO}_{2}$ and $\mathrm{SO}_{2}$ from mc-Si module production are mainly caused by the carbothermic silica reduction process. Standard measures, like the use of low-sulphur fuel and desulphurization of flue gases can may significantly reduce the $\mathrm{SO}_{2}$ emissions. Most other process emissions seem relatively small and will have little or negligible environmental impact. Possible exceptions are the water-borne $\mathrm{Cl}$-and F-emissions resulting from neutralizing etching and texturing solutions and flue gases. Compared on an energy basis the $\mathrm{Cl}$-and $\mathrm{F}$-emissions for the B case module are estimated to be resp. 89,000 and1,500 kg/TWh, which is of the order of 20-25\% of the equivalent emissions of a coal-fired electricity plant. Some attention may be necessary for emission of solvents or other volatile organic compounds from various process steps, among others from metal paste firing and -possibly module lamination. These emissions will depend highly on processing conditions and control measures. Also care should be taken to prevent accidental emissions of $\mathrm{CF}_{4}$, because this gas has a very high Global Warming Potential. The possibilities for reuse of production waste, e.g. silicon wafers and silicon carbide, should be investigated. The differences betIen respective cases for mc-Si modules are not remarkable, although emissions will decrease somewhat due to increased material efficiency.

\section{a-Si modules:-}

Apart from the remarks made above with respect to (thin-film) modules in general there are little or no significant emissions to be expected from a-Si module production, use and decommissioning. The emissions from the silane production process contribute only very little to the total emissions and can be neglected. Regarding the comparative emissions of the three a-Si cases I can conclude that the trends toward improved material utilization and loIr glass content of the module which may be expected from current R\&D efforts, will also contribute to a further reduction of the environmental impacts of a-Si module production. In total, I can say that for the assumed system boundaries and assuming proper emission control measures large-scale production of a-Si modules will not result in any serious environmental emission.

\section{CdTe and CIS modules:-}

As stated above I have only considered the material flows of the heavy metals contained in CdTe and CIS modules. A first point to note in this respect is that CdTe or CIS modules contain only a relatively small amount of heavy metals, for example B case CdTe modules contain ca. $6 \mathrm{~g}$ of cadmium per in module area. By comparison, a single NiCad penlight battery contains $2.5 \mathrm{~g}$ of cadmium. If I consider both products as an energy supplier (although NiCads are obviously not a real energy source) then I find that the amount of cadmium contained in the B case CdTe module is about $0.001 \mathrm{~g}$ per $\mathrm{kWh}$ supplied $(0.006 \mathrm{~g} / \mathrm{kWh}$ for the A case $)$, while the $\mathrm{NiCad}$ battery requires about $5 \mathrm{~g} \mathrm{Cd}$ per $\mathrm{kWh}$ supplied. For our assessment of environmental emissions I will focus on the estimated emissions of cadmium resp. selenium to the atmosphere which are summarized in tables 5.2 and 5.3. I can see that in the B case the emissions mainly occur in the resource mining (and refining) and in the module utilization phase. From A to $\mathrm{C}$ case the emissions differ by roughly a factor of 10 , reflecting the uncertainty regarding emission rates for future technology cases. Emissions of selenium are considerably higher than for cadmium because of less stringent emission control measures. It should be noted that there is some uncertainty in the assumptions underlying the emission estimates for the module utilization and decommissioning phases. Also it is important to note that the risks of cadmium (or selenium) releases to the environment from the utilization and decommissioning phases are very much dependant on the type of encapsulation that is chosen for the module. Experimental tests suggest that releases from modules with a double glass encapsulation are considerably lower than for modules without a glass cover at the backside. Unfortunately CdTe modules which are presently offered on the market often do not have a back glass cover 
Table 5.2:- Atmospheric cadmium emission from the life cycle of CdTe modules and from coal-fired electricity generation.

\begin{tabular}{|l|l|l|l|l|}
\hline & & A & B & C \\
\hline & & case & case & case \\
\hline Mining $\left(\mathrm{mg} / \mathrm{m}^{2}\right)$ & & 11 & 0.9 & 0.2 \\
\hline Module production $\left(\mathrm{mg} / \mathrm{m}^{2}\right)$ & & 8 & 0.4 & 0.05 \\
\hline Utilization $\left(\mathrm{mg} / \mathrm{m}^{2}\right)$ & & 1.8 & 1.1 & 0.5 \\
\hline Decommissioning $\left(\mathrm{mg} / \mathrm{m}^{2}\right)$ & & 1.8 & 0.2 & 0.005 \\
\hline Total Emission $\left(\mathrm{mg} / \mathrm{m}^{2}\right)$ & & 22.6 & 2.6 & 0.8 \\
\hline Emission per unit & energy & 11.8 & 0.5 & 0.1 \\
\hline (g/GWh) & & & & \\
\hline Cd emission from coal plan (g/GWh)) & & & & $0.6-10$ \\
\hline Cd emission from coal gasification plant $(\mathrm{g} / \mathrm{GWh})$ & Table 5.3 & & & $0.06-1$ \\
\hline & A--Case & B--Case & & C-Case \\
\hline & 260 & 19 & & 3.6 \\
\hline Mining $\left(\mathrm{mg} / \mathrm{m}^{2}\right)$ & & & & \\
\hline & 210 & 11 & & 1.5 \\
\hline Module & & & & \\
\hline production $\left(\mathrm{mg} / \mathrm{m}^{2}\right)$ & 25 & 15 & & 6 \\
\hline Utilization $\left(\mathrm{mg} / \mathrm{m}^{2}\right)$ & 5 & 0.5 & & 0.07 \\
\hline Decommissioning & & & & \\
\hline$\left(\mathrm{mg} / \mathrm{m}^{2}\right)$ & 500 & 45.5 & & 11.2 \\
\hline TotalEmission & & & & \\
\hline$\left(\mathrm{mg} / \mathrm{m}^{2)}\right.$ & 260 & & & 1.8 \\
\hline Emission per unit & & & \\
\hline energy & & & \\
\hline
\end{tabular}

In order to put these emission estimates into perspective I can compare them with the emissions of cadmium and selenium from coal-fired electricity generation which has been estimated at $0.6-10 \mathrm{~g} / \mathrm{GWh}$ resp. $70 \mathrm{~g} / \mathrm{GWh}$ for a modern coal poIr plant in the India. For a plant Based on coal gasification technology, however, emissions are lower, namely $0.06-1 \mathrm{~g} / \mathrm{GWh}$ for $\mathrm{Cd}$ and $60 \mathrm{~g} / \mathrm{GWh}$ for Se. I can therefore conclude that the atmospheric $\mathrm{Cd}$ emissions for the B case CdTe module of $0.5 \mathrm{~g} / \mathrm{GWh}(0.9 \mathrm{~g} / \mathrm{GWh}$ in the India) are lower than those of a modern coal power plant, but may be higher than for a coal gasification power plant. With regard to CIS modules the B case Se emissions to the air are significantly lower than Se emissions both from conventional coal plants and from coal gasification plants. An important point to note in this respect is that coal-fired plants have many more emissions(a.o. $\mathrm{SO}_{2}, \mathrm{NO}_{\mathrm{x}}, \mathrm{Cl}, \mathrm{F}, \mathrm{B}, \mathrm{Cr}, \mathrm{Hg}, \mathrm{Pb}$ ) which are often larger than the $\mathrm{Cd}$ or Se emissions. For CdTe or CIS modules, on the other hand, cadmium respectively selenium will be one of the few environmentally relevant emissions. A second way to put the results above into perspective is to compare the estimated emissions with the total emissions of $\mathrm{Cd}$ or Se from all existing economic activities. Consider for example situation where 5\% of the current Indian electricity production would be generated by $\mathrm{B}$ case $\mathrm{CdTe}$ or CIS modules. The resulting $\mathrm{Cd}$ and $\mathrm{Se}$ emissions from this activity. would then be $3.5 \mathrm{~kg} / \mathrm{yr}$ respectively $60 \mathrm{~kg} / \mathrm{yr}$, which is equivalent to $0.2 \%$ resp. $0.6 \%$ of the current total emissions of $\mathrm{Cd}$ and $\mathrm{Se}$ in the India. The evaluation whether emissions as estimated above may be acceptable for society or not remains a difficult problem and in the end it is a political choice. However, it seems to us that the results above give no reason for immediate concern, although it would be good if the range of uncertainty could be reduced.

\section{Module decommissioning and recycling options:-}

After their useful lifetime the solar cell system will be dismantled and resulting waste streams will have to treated in a responsible manner. In this section we will consider some issues of module waste management and discuss recycling possibilities.

\section{mc-Si modules:-}

Mc-Si modules consist mainly of glass (78 wt. \%), with smaller fractions of EVA (10 wt.\%),polyester (7\%) and silicon (4 wt. \%) all rather harmless materials. However, small amounts of silver (0.4 wt. \%) and copper (0.3 wt.\%) 
for the A case module are also in the module waste in concentrations which are just below the threshold value for "Dangerous Waste" (0.5 wt \%)according to Indian environmental regulations. As yet there is no commercial process available for recycling of mc-Si modules. Recycling of the module cover glass should be possible if methods are developed to separate it from the EVA and other module components. Recycling of module glass with adherent EVA will meet some restrictions (see below under a-Si modules). Methods for reclaiming the silicon wafers from a (rejected) module have been investigated, but to our knowledge they are not commercially applied up to now.

\section{a-Si modules:-}

a-Si modules consist mainly of glass and can therefore be used as feedstock for secondary glass production (glass recycling). Recent experiments have shown that the only restrictions are the modules should mainly be used for production of coloured packing glass and that the fraction of module waste in the total feedstock should remain below $10 \%$. These restrictions, however, would not pose any serious limitations on future a-Si module deployment Also it has been demonstrated that it is technically possible to re-use a glass substrate (including the TCO layer) after etching off the a-Si and back contact layers from anon-encapsulated module. This approach may be interesting for the reprocessing of rejected modules in a module production plant.

\section{CdTe/CIS modules:-}

The heavy metal content of CdTe and CIS modules would require them to be treated as "Dangerous Waste" under the existing regulations in the India. On the other hand, at least one type of commercially available CdTe modules has been shown to meet the proposed EC regulations for waste disposal in land fill sites. The heavy metal content of $\mathrm{CdTe} / \mathrm{CIS}$ modules makes them less attractive as feedstock for secondary glass production. One viable option for disposal is to feed the modules into non-ferrous smelters. Although no estimates are available at this time, it would seem that the total volume of module waste which can be disposed of in this way is rather limited, so that it is probably not a long-term solution. If large scale deployment of CdTe or CIS modules is considered then the recovery of the heavy metals from the module waste will probably be required, from the viewpoint of both waste management and resource management. It appears that hydrometallurgical methods offer the $\mathrm{C}$ prospects for such a metal recovery process, although effective extraction of the metals from an encapsulated module may be problematic. Also the low concentration of metals would probably lead to added cost for the recycling process.

\section{Conclusions:-}

From our analyses we conclude that for the immediate future and within the considered system boundaries there are no reasons for concern regarding the material requirements and emissions of solar cell modules. Only if large scale deployment of modules -with annual production levels of several GW's -becomes probable there are some points which need closer attention, namely:

* resource depletion of silver (mc-Si modules);

* resource depletion of indium (CIS modules) *waste management and recycling possibilities for decommissioned modules (mc-Si, CdTe, CIS); *cumulative fire-induced emissions from CdTe and CIS modules.

Although there is still a considerable range of uncertainty in our emission estimates the risks from cadmium or selenium use in CdTe respectively CIS modules seem acceptable in comparison with some existing products or services like NiCad batteries or coal-fired electricity production.

\section{Health and safety risks:-}

In this topic we will shortly review occupational health and safety risks and external safety risks. Public health risks are not discussed here because they are a consequence of the emissions discussed in the previous chapter. Moreover, the estimation of public health risks from emission data was not part of our study scope because it is a very complex task. we will focus here on risks resulting from module production. One general point of attention for module installation and use are the electrical shock hazards. However, with a proper design of the electrical lay-out so that dc voltages are either kept below $110 \mathrm{~V}$ or higher voltages are properly shielded, no serious risks should result.

\section{mc-Si module:-}

No serious health and safety risks are expected for workers involved in mc-Si module production. Exposure to etchants like $\mathrm{HF}, \mathrm{HNO}_{3}$ and $\mathrm{HCl}$ and exposure to silane or other hydrides poses a moderate risks, which should be controllable within normal safety procedures. External safety risks seem small for mc-Si module production, only 
the storage of silane should be performed with the proper safeguards (see under a-Si below). Silane use is, however, much smaller than for a-Si module production.

\section{a-Si modules:-}

Silane, the primary feedstock gas in a-Si module production, is a highly flammable gas which may ignite spontaneously in air. Because self-ignition does not always occur, large gas clouds may build up which can cause a severe explosion. Proper control measures are therefore necessary to prevent these situations. There is a review on various control measures for storage and handling of hazardous gasses in a-Si module production facilities. However, no detailed risk analysis are known of installations where silane and the other hydrides are handled in the amounts needed for a 10-50 MWp PV production capacity. Therefore, reliable statements on the safety risks of large-scale a-Si production facilities cannot be made with the available data.

\section{CdTe and CIS modules:-}

First of all one should note that CdTe and CIS contain only little toxic material .Moreover the toxicity of ingested CdTe appears to be relatively low because of its low solubility. Obviously, the exposure to cadmium of workers in a module production plant should be kept as low as possible. Current practices in such plants have proven to be more than sufficient in this respect, so there appears to be no reason for concern about occupational health risks if proper measures have been taken. Recent studies have furthermore shown that there is negligible risk of dangerous exposure to cadmium from a stock of CdTe modules during a fire. This should also rule out acute health risks due to fires in roof-top PV installations. Regarding selenium the exposure limits for air-borne material are a factor 10 higher than for cadmium compounds so it should be relatively easy to keep occupational Se exposures at acceptable levels. Furthermore the toxicity of elementary selenium appears to be moderate (upto now toxicity data on CuInSe ${ }_{2}$ itself are very limited); therefore the main health risk from CIS appears to be exposure to $\mathrm{SeO}_{2}$ which may be formed at temperatures above 350 C.A major risk factor of CIS module production can be the use of hydrogen selenide, which may be used as a feedstock gas in the $\mathrm{CuInSe} \mathrm{I}_{2}$ deposition process. An accidental release of $25 \mathrm{~kg}$ (=one typical gas container) of $\mathrm{H}_{2} \mathrm{Se}$ can lead to dangerous exposure levels in an $40 \mathrm{~m} \times 3000 \mathrm{~m}$ area. However, there are alternative CIS deposition methods available which do not require the use of $\mathrm{H}_{2} \mathrm{Se}$.

\section{Conclusions:-}

The only significant risks regarding occupational health and safety and external safety are found in the storage and handling of explosive and/or toxic gasses, i.e. silane in a-Si production and $\mathrm{H}_{2} \mathrm{Se}$ in certain CIS deposition processes. With proper safety measures in place silane risks seem to be Ill manageable, but still the issue of silane storage at large-scale a-Si module production facilities (>10 MWp/yr) remains a point of attention. Regarding CIS module production it is advisable to avoid deposition methods involving the use of hydrogen selenide gas.

The environmental aspects of four major solar cell technologies have been revieId with special attention for future expected technology developments. Cell technologies investigated are multicrystalline silicon (mc-Si), amorphous silicon (a-Si), cadmium telluride (CdTe) and $\mathrm{CuInSe}_{2}$ (CIS). The following aspects are considered: energy requirements and energy pay-back time, material requirements and resource depletion, environmental emissions, waste handling, possibilities for recycling of modules, occupational health and safety and external safety. Although the energy pay-back time of the present-day mc-Si and a-Si modules is relatively high, around 4 to 4.5 years for frameless modules under Indian irradiation conditions, this pay-back time is still considerably shorter than the expected technical lifetime of the module (15-30 years). Moreover, very good prospects exist for reduction of energy requirements by future technology developments, resulting in energy pay-back times below 1.5 years for all module types (under Indian irradiation conditions; below 1 year for global average irradiation). It is remarkable that thin film technologies (a-Si, CdTe, CIS) do not score significantly better (in some cases even worse) as wafer-Based mc-Si technology. This mainly caused by the superior efficiency of mc-Si cells. Note that frames and support structures can add substantially to the energy requirements and may double the energy pay-back time of the total PV system (compared to modules only). Therefore serious attention is necessary for designs of array support structures which have a low energy requirement. From our analyses of the material flows we conclude that for the immediate future (and within the considered system boundaries) there are no reasons for concern regarding the material requirements and emissions of solar cell modules. Only if large scale deployment of modules -with annual production levels of several GW's -becomes probable there are some points which need closer attention, namely:

* $\quad$ resource depletion of silver (mc-Si modules);

* $\quad$ resource depletion of indium (CIS modules);

* Waste management and recycling possibilities for decommissioned modules (mc-Si, CdTe, CIS);

* $\quad$ cumulative fire-induced emissions from CdTe and CIS modules. 
Although there is still a considerable range of uncertainty in our emission estimates the risks from cadmium or selenium use in CdTe respectively CIS modules seem acceptable in comparison with some existing products or services like NiCad batteries or coal-fired electricity production. Regarding occupational health and safety and external safety the only significant risks are found in the storage and handling of explosive and/or toxic gasses, i.e. silane in a-Si production and $\mathrm{H}_{2} \mathrm{Se}$ in a certain CIS deposition process. With proper safety measures in place silane risks seem to be Ill manageable, but use of hydrogen selenide gas should be avoided. Finally, table 7.1 presents a qualitative comparison of these cell types on the aspects mentioned above. we can see that there is not one single cell type that scores good or excellent on all considered aspects, although future a-Si technology, seems to be the most "environmentally friendly" technology, with mc-Si as a good second. CIS and CdTe score less Ill because of problems related to the use of heavy metals, some of which are rather scarce. However, these problems should not be considered as a major bottle-neck for the immediate future. Therefore they should not be used as a reason for ruling out one or more of the considered solar cell technologies from further R\&D efforts.

Table 7.1: Qualitative comparison of the investigated solar cell technologies. Present respectively future indicates the assumed technology status with regard to module production, emission control technology and recycling. Scores for present technology are Based on the A case results described in previous chapters, while scores for future technology are Based on both B case (70\%) and C case results (30\%). Note that effects of increasing production volumes, leading for example to increasing emissions, are not considered between present and future technology.

Cell Characteristics for CDTe Technology

\begin{tabular}{|c|c|c|c|}
\hline & A--Case & B--Case & C-Case \\
\hline CdS layer $(\mu \mathrm{m})$ & 0.2 & 0.15 & 0.1 \\
\hline CdTe layer( $\mu \mathrm{m})$ & 4 & 2 & 1 \\
\hline $\operatorname{Efficiency}(\%)$ & 10 & 15 & 18 \\
\hline \multicolumn{4}{|c|}{ Cell Characteristics for CIS Technology } \\
\hline & A--Case & B--Case & C-Case \\
\hline CdS layer $(\mu \mathrm{m})$ & 0.1 & 0.05 & 0.1 \\
\hline $\mathrm{CuInSe}_{2}$ & 4 & 2 & 1 \\
\hline \multicolumn{4}{|l|}{ layer $(\mu \mathrm{m})$} \\
\hline Efficiency(\%) & 10 & 15 & 18 \\
\hline
\end{tabular}

All in all we conclude from our investigations that -at least for the immediate future -there are no major bottlenecks from environmental point of view for the considered solar cell technologies. However, during module production substances are used which may be harmful for workers, the public or the environment. Therefore manufacturers should take proper measures to avoid harmful exposures or emissions.Points which deserve further attention both from manufacturers and researchers are: the energy requirements of modules (and module frames and supports), the use of heavy metals, gas safety issues and module recycling possibilities.

\section{References:-}

1. A.R.Burgers. How to design optimal metallization patterns for solar cells. Progress in Photovoltaics:Research and Application

2. Martin Green. High Efficiency Silicon Solar Cells. Trans Tech Publications, 1987

3. J.Coello, M.Castro, I., and M.A.Vazquez. Conversion of commercial vsi solar cells to keep their efficient performance. Progress in Photovoltaics Research and Applications

4. J.Zhao. Recent advances of high efficiency single crystalline silicon solar cells in processing technologies and substrate materials. Solar Energy Materials and Solar cells

5. L.L.Kazmerski. Solar photovoltaic $\mathrm{r} \& \mathrm{~d}$ at the tipping point:a 2005 technology overview. Journal of Electron Spectroscopy and Related Phenomena,

6. de Wild-Scholten, M.J. and E.A. Alsema, Environmental Life Cycle Inventory of Crystalline Silicon Photovoltaic Module Production, Proceedings of MRS Fall 2005 Meeting, Symposium G, Boston, MS, Nov-Dec 2005.

7. Ecoinvent database version 1.2.See http://www.ecoinvent.ch/

8. Müller, A., K. Wambach and E.A. Alsema, Life Cycle Analysis of Solar Module Recycling

9. Process, Proceedings of MRS Fall 2005 Meeting, Symposium G, Boston, MS, Nov-Dec 2005. 